Original Article

\title{
Phytochemical characterization, and antioxidant and antibacterial activities of the hydroethanolic extract of Anadenanthera peregrina stem bark
}

\author{
Caracterização fitoquímica, atividade antioxidante e antibacteriana do extrato \\ hidroetanólico de cascas do caule de Anadenanthera peregrina
}

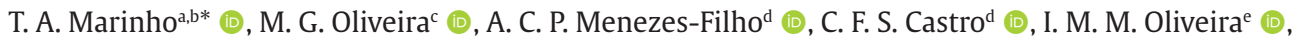 \\ L. L. Borges ${ }^{f}$ (D), P. R. Melo-Reis' (D) and N. J. Silva-Jr' ${ }^{g}$ (D) \\ aUniversidade Federal de Goiás - UFG, Rede Pró Centro-Oeste, Programa de Pós-graduação em Biotenologia e Biodiversidade - PGBB, Goiânia, \\ GO, Brasil \\ 'Instituto Federal de Educação, Ciência e Tecnologia de Goiás - IFG, Núcleo de Estudos e Pesquisas em Promoção da Saúde - NUPPS, Goiânia, GO, Brasil \\ 'Universidade Federal de Goiás - UFG, Programa de Pós-graduação em Ciências Farmacêticas, Goiânia, GO, Brasil \\ dInstituto Federal de Ciência e Tecnologia Goiano - IFGoiano, Programa de Pós-graduação em Agroquímica - PPGAq, Rio Verde, GO, Brasil \\ ePontifícia Universidade Católica de Goiás - PUCGO, Programa de Pós-graduação em Genética, Goiânia, GO, Brasil \\ fUniversidade Estadual de Goiás - UEG, Programa de Pós-graduação em Recursos Naturais do Cerrado - RENAC, Anápolis, GO, Brasil \\ gPontifícia Universidade Católica de Goiás - PUCGO, Programa de Pós-graduação em Ciências Ambientas e Saúde, Goiânia, GO, Brasil
}

\begin{abstract}
The Brazilian Cerrado biome consists of a great variety of endemic species with several bioactive compounds, and Anadenanthera peregrina (L.) Speg is a promising species. In this study, we aimed to perform phytochemical characterization and evaluate the antioxidant and antibacterial activities against Staphylococcus aureus and Escherichia coli of the hydroethanolic extract of A. peregrina stem bark. The barks were collected in the Botanical Garden of Goiânia, Brazil. The hydroethanolic extract was obtained by percolation and subjected to physicochemical screening, total phenolic content estimation, high-performance liquid chromatography (HPLC) fingerprinting, and antioxidant ( $\mathrm{IC}_{50}$ values were calculated for the 2,2-diphenyl-1-picrylhydrazyl assay - DPPH) and antibacterial activity determination. The $\mathrm{pH}$ of the extract was 5.21 and density was $0.956 \mathrm{~g} / \mathrm{cm}^{3}$. The phytochemical screening indicated the presence of cardiac glycosides, organic acids, reducing sugars, hemolytic saponins, phenols, coumarins, condensed tannins, flavonoids, catechins, depsides, and depsidones derived from benzoquinones. The extract showed intense hemolytic activity. The total phenolic content was $6.40 \mathrm{~g}$ GAE $100 \mathrm{~g}^{-1}$. The HPLC fingerprinting analysis revealed the presence of gallic acid, catechin, and epicatechin. We confirmed the antioxidant activity of the extract. Furthermore, the extract did not inhibit the growth of $E$. coli colonies at any volume tested, but there were halos around S. aureus colonies at all three volumes tested. These results contribute to a better understanding of the chemical composition of $A$. peregrina stem bark and further support the medicinal applications of this species.
\end{abstract} Keywords: products with antimicrobial activity, high pressure liquid chromatography, HPLC, medicinal plants, phenolic compounds.

\begin{abstract}
Resumo
O bioma Cerrado brasileiro apresenta em uma grande variedade de espécies endêmicas com diversos compostos bioativos, e Anadenanthera peregrina (L.) Speg é uma espécie promissora. Neste estudo, objetivamos realizar a caracterização fitoquímica e avaliar as atividades antioxidantes e antibacterianas contra Staphylococcus aureus e Escherichia coli do extrato hidroetanólico de cascas do caule de A. peregrina. As cascas foram coletadas no Jardim Botânico de Goiânia, Brasil. O extrato hidroetanólico foi obtido por percolação e submetido a triagem físicoquímica, estimativa de conteúdo fenólico total, impressão digital por cromatografia líquida de alta eficiência (HPLC) e determinação da atividade antioxidante (valores de IC50 foram calculados para o ensaio 2,2-difenil-1picril-hidrazil) e antibacteriana. $\mathrm{O} \mathrm{pH}$ do extrato foi de 5,21 e a densidade foi de $0,956 \mathrm{~g} / \mathrm{cm}^{3}$. A triagem fitoquímica indicou a presença de glicosídeos cardíacos, ácidos orgânicos, açúcares redutores, saponinas hemolíticas, fenóis, cumarinas, taninos condensados, flavonóides, catequinas, depsídios e depsidonas derivados de benzoquinonas. O extrato mostrou intensa atividade hemolítica. O conteúdo fenólico total foi de $6,40 \mathrm{~g}$ de GAE $100 \mathrm{~g}^{-1}$. A análise por impressão digital por HPLC revelou a presença de ácido gálico, catequina e epicatequina. Confirmamos a atividade antioxidante do extrato. Além disso, o extrato não inibiu o crescimento de colônias de E. coli em nenhum
\end{abstract}

*e-mail: tamiris.marinho@ifg.edu.br

Received: February 27, 2020 - Accepted: July 3, 2020

This is an Open Access article distributed under the terms of the Creative Commons Attribution License, which permits unrestricted use, distribution, and reproduction in any medium, provided the original work is properly cited. 
volume testado, mas houve halos em torno das colônias de $S$. aureus nos três volumes testados. Estes resultados contribuem para uma melhor compreensão da composição química da casca de A. peregrina e apoia ainda mais as aplicações medicinais desta espécie.

Palavras-chave: produtos com ação antimicrobiana, cromatografia líquida de alta velocidade, HPLC, plantas medicinais, compostos fenólicos.

\section{Introduction}

The World Health Organization (WHO) encourages countries to generate evidence-based policies and strategic plans for the use of medicinal plants (WHO, 2019). In this context, in Brazil, there are several medicinal plants that are used as herbal medicines by the rural and urban populations (Dutra et al., 2016; Pio et al., 2019). A single species can produce numerous chemical compounds with diverse pharmacological activities (Mendonça et al., 2019), including antibacterial (Pandini et al., 2018; Emre et al., 2020; Pacheco et al., 2020), anti-inflammatory (Ribeiro et al., 2018; Almohawes and Alruhaimi, 2020), antioxidant (Barth et al., 2018; Pontes et al., 2019; Vale et al., 2019), wound-healing properties (Ribeiro Neto et al., 2020), antihyperglycemic effect (Silva et al., 2020), and cardiovascular activity (Moreira et al., 2019).

The Cerrado, considered a hotspot of global biodiversity, is the second largest biome in South America, covering approximately $22 \%$ of the national territory. It is recognized as the richest savanna in the world, with 11.627 native plant species. In addition to environmental aspects, the Cerrado has social importance to the local population that uses its natural resources, including 220 medicinal species (Brasil, 2019). Some species in the Cerrado, such as Stryphnodendron adstringens (barbatimão) (Almeida et al., 2010; Ribeiro et al., 2014; Queiroz et al., 2021), Macairea radula (capuchina), and Pterodon emarginatus (sucupira) (Vila Verde et al., 2018), have been studied.

Phenolic compounds, mainly tannins, are responsible for the therapeutic activity of different plants in the Cerrado. They have been identified in the following plants in the Cerrado: Hymenaea stignocarpa (jatobá-do-cerrado) (Silva et al., 2019), Caryocar spp. (pequi) (NascimentoSilva and Naves, 2019), Inga laurina (ingá) (Martins et al., 2019), Annona crassiflora (araticum) (Arruda et al., 2018), and Passiflora alata (maracujá-doce) (Pereira et al., 2018), making this biome a source of promising medicinal species for bioprospecting studies (Bailão et al., 2015).

The genus Anadenanthera has two species, Anadenanthera colubrina, which has a wide geographical coverage, and Anadenanthera peregrina, typical to the Brazilian Cerrado (Morim, 2015; Carvalho, 2003). Anadenanthera peregrina is distributed in the drainage areas, gallery forests, and rocky fields in the Cerrado. Popularly known as angico, A. peregrina, a rustic species of canopy-forming trees, resists drought and fire due to its thick bark that protects the plant (Souza et al., 2014). According to Mota et al. (2017), the bark of A. peregrina is a potential source of polar extracts, enabling the extraction of tannins that represent approximately $17 \%$ of the bark (173.3 $\mathrm{mg} \mathrm{CE} \mathrm{g}^{-1}$ bark) and $59 \%$ of the hydroalcoholic extract (in catechin equivalents). The bark and seeds of Anadenanthera are used to treat wounds (Pessoa et al., 2012, 2015) and respiratory diseases, owing to the antioxidant, anti-inflammatory, and antimicrobial properties (Weber et al., 2011; Gama et al., 2018).

A pharmacological study on the major species in the Cerrado reported that the stem and resin of A. peregrina prepared as decoctions or syrups, or macerated in cachaça and wine have potential to treat bronchitis and influenza (Souza et al., 2016). However, data on the phytochemical properties, and antioxidant (Mota et al., 2017) and antibacterial activities of $A$. peregrina stem bark, which is an important part of the plant used for therapeutic purposes, are limited. Therefore, in this study, we aimed to perform phytochemical analysis and evaluate the antioxidant and antibacterial activities of the hydroethanolic extract of A. peregrina stem bark.

\section{Materials and Methods}

\subsection{Plant material and extraction}

The stem barks of $A$. peregrina were collected from three plants in the Botanical Garden of Goiânia, Goiás State, Brazil ( $\left.16^{\circ} 43^{\prime} 22^{\prime \prime S}, 49^{\circ} 22^{\prime} 54^{\prime \prime} \mathrm{W}\right)$, with a diameter at breast height (DBH) of 110,105 , and $107 \mathrm{~cm}$. The species was identified and authenticated by Dr. Lorena Lana Camelo Antunes, at the Laboratory of Plant Morphology and Taxonomy of the Federal University of Goiás, and a sample has been deposited in the herbarium of the same University (voucher code number: 61.014).

To obtain the extract, the barks were ground in a knife mill with Tamis 20 mesh (TE-625; Tecnal Ltd., Piracicaba, São Paulo, Brazil); then, $1000 \mathrm{~g}$ of the ground barks sample was percolated (Revitec Ltd., São Paulo, São Paulo, Brazil) with $5000 \mathrm{~mL}$ of hydroethanolic solution (50:50 v/v) for $24 \mathrm{~h}$ in a metal percolator with a Tamis 200 mesh lined with a layer of paper towel and cotton to filter the barks particles. Next, it was extracted exhaustively $\left(0.2 \mathrm{~mL} . \mathrm{min}^{-1}\right)$ at room temperature (percolation phase). Subsequently, the extract was evaporated at $40{ }^{\circ} \mathrm{C}$ in a rotary evaporator (TE211; Tecnal Ltd., Piracicaba, São Paulo, Brazil) under reduced pressure (vacuum pump - TE0581; Tecnal Ltd., Piracicaba, São Paulo, Brazil). The extract obtained $(2500 \mathrm{~mL})$ was stored in a closed refrigerated container $\left(-2^{\circ} \mathrm{C}\right.$ to $\left.+8^{\circ} \mathrm{C}\right)$ until further analysis. Posteriorly, after the rotavaporated hydroalcoholic extract was produced and using the Moisture Meter with an infrared heat source (ID 200; Scientific Mars), at $150^{\circ} \mathrm{C}$, the extract concentration was determined as $124 \mathrm{mg} / \mathrm{mL}$, based on the content of solids in triplicate (Brasil, 2010).

\section{2. $\mathrm{pH}$ and density}

The $\mathrm{pH}$ and relative density of the hydroalcoholic extract were determined as described by Longhini et al. (2007). 


\subsection{Preliminary phytochemical screening}

Phytochemical screening was performed according to the procedure described by Menezes Filho and Castro (2018), for each phytochemical test, $3 \mathrm{~mL}$ of the extract was used. The reaction intensity was visually determined using the cross test: $(+++)$ highly positive, $(++)$ moderately positive, $(+)$ less positive, and (-) negative (Marín et al., 2018). Hemolytic activity was determined at 1 and $10 \mathrm{~min}$ of reaction of the extract with $5 \%$ red cell suspension. Optical micrographs were obtained to observe the hemolysis reaction.

\subsection{Determination of phenolic compounds}

The total phenolic compounds were determined as described by Menezes Filho et al. (2018), using the colorimetric method with Folin-Ciocalteu reagent. The results are expressed as gallic acid equivalent (GAE) $100 \mathrm{~g}^{-1}$ dry weight.

\subsection{High-Performance Liquid Chromatography (HPLC) fingerprinting}

The HPLC analysis was performed using Waters Alliance with the e2695 separation module and 2998 photodiode array detector; data were acquired using Empower software. Chromatographic separations were carried out using the Zorbax Eclipse XDB-C18 reversedphase column $(250 \mathrm{~mm} \times 4.6 \mathrm{~mm}, 5 \mu \mathrm{m})$. The column temperature was maintained at $35^{\circ} \mathrm{C}$ and the injection volume was $10 \mu \mathrm{L}$. The mobile phases were $0.05 \%$ formic acid in acetonitrile $(\mathrm{pH}=3.45)$ (solvent $\mathrm{A}$ ) and $0.05 \%$ formic acid in water $(\mathrm{pH}=3.15)$ ( solvent $\mathrm{B}$ ) at a flow rate of $1 \mathrm{~mL} \mathrm{~min}^{-1}$. The gradient applied was as follows: $0-5 \%$ A (0-5 min); 5-10\% A (5-15 min); 10-15\% A (15-25 min), $15-20 \% \mathrm{~A}$ (25-35 $\mathrm{min})$, and then isocratic $15 \mathrm{~min}$ of $20 \%$ A (35-50 min). The mobile phases were filtered through a $0.45-\mu \mathrm{m}$ polyvinylidene fluoride (PVDF) membrane and degassed using an ultrasonic bath.

For the analysis, $1 \mathrm{~mL}$ of the extract was diluted in $5 \mathrm{~mL}$ of methanol in a volumetric flask. To identify the peaks separated by HPLC, stock solutions $\left(0.1 \mathrm{mg} \mathrm{mL}^{-1}\right.$ in methanol) of the following standards, procured from Sigma Aldrich, were used: caffeic acid, caffeine, catechin, chlorogenic acid, ellagic acid, epicatechin, gallic acid, hesperidin, kaempferol, $p$-coumaric acid, quercetin, and rutin. The chromatograms were recorded at the wavelengths of 254, 327, and $366 \mathrm{~nm}$, according to the different absorptions of each compound evaluated. The compounds were identified by comparing the HPLC chromatograms of the extract and those of the pure standards based on the retention time $\left(\mathrm{R}_{\mathrm{t}}\right)$ and UV spectra in the wavelength range of 190-400 nm. Before injection, the solutions were filtered through a $0.45 \mu \mathrm{m}$ PVDF membrane.

\subsection{Antioxidant activity determination}

The antioxidant activity was determined as described by Menezes Filho et al. (2018). The results are expressed as the extract concentration at which $50 \%$ of 2,2-diphenyl-1picrylhydrazyl (DPPH) free radicals were inhibited $\left(\mathrm{IC}_{50}\right)$.

\subsection{In vitro antibacterial activity of A. peregrina extract}

Under a laminar flow hood, Staphylococcus aureus ATCC 25923 and Escherichia coli ATCC 25922 samples were thawed to room temperature, and then transferred to trypticase soy broth (TSB) liquid culture medium for sample dilution and incubated at $37^{\circ} \mathrm{C}$ for $4 \mathrm{~h}$. The activated strains were inoculated on Cled Agar and incubated at $37^{\circ} \mathrm{C}$ for $24 \mathrm{~h}$ for the isolation of colonies. Using a sterile loop, the colonies were transferred to selective media, MacConkey for E. coli and mannitol salt agar for S. aureus; after $24 \mathrm{~h}$, the isolated colonies were verified.

Using sterile loops, the isolated colonies were collected from each selective medium, and then a bacterial suspension in saline solution $(0.85 \% \mathrm{NaCl})$ was prepared for each strain until the turbidity reached 0.5 on the McFarland scale. For this procedure, a McFarland 0.5 calibrated tube was used as the reference. A swab soaked in bacterial suspension solution was inoculated (for each sample) on Mueller-Hinton agar, covering the entire plate. Immediately, wells of diameter $10 \mathrm{~mm}$ were created in the agar plate using autoclave and ultraviolet light-sterilized glass tubes. Each well was identified with letters A, B, and $C$ and filled with 50,100 , and $200 \mu \mathrm{L}$ A. peregrina extract, respectively. Meropenem discs were used as the positive control and $200 \mu \mathrm{L}$ of saline solution as the negative control. The plates were incubated in a bacteriological oven for $24 \mathrm{~h}$. There were five replicates for each microorganism on different days (Silveira et al., 2009).

\section{Results}

\subsection{Preliminary phytochemical screening}

The extract was clear, homogeneous, and dark brown. Table 1 presents the results of the preliminary phytochemical screening. The hydroethanolic extract of A. peregrina stem bark was positive for glycosides, based on the moderate-intensity reaction with Kedde and Keller-Kiliani reagents, and a highly positive reaction with Raymond-Marthoud reagent. However, the result of Baljet reagent test was negative. The reaction with Baljet and Kedde reagents was positive due to the presence of compounds with cardenolide unsaturated pentagonal lactone ring. The reaction with Keller-Kiliani reagent was positive due to the presence of deoxygenating compounds (deoxysugar) with a free end. The reaction was positive with Raymond-Marthoud reagent due to the presence of an aglycone (genin), a non-glycidyl group that forms a part of glycosides.

The extract showed negative results in the tests for alkaloids, including the Libermann-Bouchardat, Wagner, and Mayer tests. The test for organic acids was positive with medium intensity according to the cross test. The test with Fehling's reagent for reducing sugars was also positive. The test for coumarins was positive. Foamed saponins were not observed in the extract.

A strong hemolysis was observed in a short time, that is, 1-10 min after incubation of the hydroethanolic extract with red blood cell suspension (Figure 1). Furthermore, in the micrographs, erythrocyte hemolysis was apparent.

The extract showed a positive reaction for condensed tannin compounds and intense reaction in the tests for 
Table 1. Phytochemical prospecting of the main secondary metabolite groups of the hydroethanolic extract of $A$. peregrina stem bark.

\begin{tabular}{|c|c|}
\hline Secondary metabolite & $\begin{array}{l}\text { Hydroethanolic } \\
\text { extract of } \\
\text { A. peregrina }\end{array}$ \\
\hline \multicolumn{2}{|l|}{ Cardiac glycosides } \\
\hline Kedd reagent test & ++ \\
\hline Keller-Kiliani reagent test & ++ \\
\hline Baljet reagent test & - \\
\hline Raymond-Marthoud reagent test & +++ \\
\hline \multicolumn{2}{|l|}{ Alkaloids } \\
\hline Libermann-Bouchardat reagent test & - \\
\hline Wagner reagent test & - \\
\hline Mayer's reagent test & - \\
\hline \multicolumn{2}{|l|}{ Organic acids } \\
\hline Pascová reagent test & ++ \\
\hline \multicolumn{2}{|l|}{ Reducing sugars } \\
\hline Fehling reagent test & ++ \\
\hline \multicolumn{2}{|l|}{ Non-reducing sugars } \\
\hline Fehling $+\mathrm{HCl}$ test & - \\
\hline \multicolumn{2}{|l|}{ Coumarins } \\
\hline UV light 254 and $365 \mathrm{~nm}$ & + \\
\hline \multicolumn{2}{|l|}{ Saponins } \\
\hline Foamy & - \\
\hline Haemolytic & +++ \\
\hline \multicolumn{2}{|l|}{ Polysaccharides } \\
\hline Reactive lugol & - \\
\hline \multicolumn{2}{|l|}{ Phenols } \\
\hline $\mathrm{FeCl}_{3}$ & +++ \\
\hline \multicolumn{2}{|l|}{ Tannins } \\
\hline $\mathrm{FeCl}_{3}$ & $\mathrm{Gr}$ \\
\hline \multicolumn{2}{|l|}{ Flavonoids } \\
\hline $\mathrm{Pb}\left(\mathrm{C}_{2} \mathrm{H}_{3} \mathrm{O}_{2}\right)_{2}$ & ++ \\
\hline Purines & - \\
\hline Catechins & +++ \\
\hline Benzoquinone derivatives & +++ \\
\hline Depsids and depsidones & +++ \\
\hline Steroids and triterpenoids & - \\
\hline Sesquiterpenolactones & - \\
\hline
\end{tabular}

Cross test: $(+++)$ positive high, $(++)$ moderate positive, $(+)$ low positive and $(-)$ negative; $\mathrm{Gr}=\mathrm{Green}$ (catechins). catechins and flavonoids. Benzoquinone and depside and depsidone derivatives were detected in the extract, based on the positive results with an intense reaction in the respective tests. The tests for purine compounds, steroids, triterpenoids, and sesquiterpene lactones were negative.

\subsection{HPLC fingerprinting analysis}

The data obtained from the HPLC fingerprinting analysis revealed that the following compounds were present in the extract: gallic acid (the $\mathrm{R}_{\mathrm{t}}$ for extract and standard was 6.735 and $6.648 \mathrm{~min}$, respectively), catechin (the $R_{t}$ for extract and standard was 16.375 and 16.479 min, respectively), and epicatechin (the $\mathrm{R}_{\mathrm{t}}$ for extract and standard was 21.335 and $21.387 \mathrm{~min}$, respectively); the UV spectra of the extract and standard were identical. The chromatogram is shown at the wavelength of $254 \mathrm{~nm}$, at which all compounds identified can be visualized (Figure 2).

\subsection{Physicochemical properties and antioxidant activity}

Table 2 presents the results of the physicochemical analysis and antioxidant activity assays, reduction of DPPH free radical and total phenol content expressed in $\mathrm{g}$ of gallic acid $100 \mathrm{~g}^{-1}$ extract. The $\mathrm{pH}$ of the hydroalcoholic extract of the stem bark of $A$. peregrina was 5.21. The relative density was $0.956 \mathrm{~g} / \mathrm{cm}^{3}$. The antioxidant activity expressed as IC was $44.13 \mathrm{mg} \mathrm{mL}^{-1}$ for extract and $0.25 \mathrm{mg} \mathrm{mL}^{-1}$ for butylated hydroxy toluene (BHT). Although the $\mathrm{IC}_{50}$ value of BHT was lower than that of the extract, the results showed that the plant material possess antioxidant activity. The total



\subsection{Antibacterial activity}

The antibacterial activity of the extract is presented in Table 3. After $24 \mathrm{~h}$ of incubation, the extract did not inhibit E. coli colonies at any extract volume tested. There were halo regions around $S$. aureus colonies at all three volumes tested. Using a millimeter ruler, the diameter of inhibitory zones was measured, excluding the diameter of the wells.

\section{Discussion}

The hydroethanolic extract of $A$. peregrina stem bark showed a positive result in the Raymond-Marthoud, Kedde, and Keller-Kiliani tests for glycosidic compounds, although the result was negative in the Baljet test. Aglycones or genin compounds are characterized by the cyclopentanoperhydrophenanthrene structural core. There are two groups of cardiac glycosides: (1) cardenolides, 23-carbon chain compounds in which the unsaturated lactone ring is attached to the pentacyclic C-17 and (2) bufadienolides, compounds with 24 hexacyclic carbons (Kloss et al., 2016). These cardiotonic compounds directly

Table 2. Physicochemical properties, antioxidant activity, and total phenolic content of the hydroethanolic extract of A. peregrina stem bark.

\begin{tabular}{|c|c|c|c|c|}
\hline Sample & $\mathbf{p H}$ & Density $\left(\mathrm{g} \mathrm{cm}^{3}\right)$ & $\mathrm{DPPH}\left(\mathrm{IC}_{50}\right)$ & Total Phenolics (g GAE $100 \mathrm{~g}^{-1}$ ) \\
\hline A. peregrina extract & $5.21 \pm 0.01$ & 0.956 & $44.13 \mathrm{mg} \mathrm{mL}^{-1}$ & $6.40 \pm 0.08$ \\
\hline
\end{tabular}

Means of three experiments followed by ( \pm ) standard deviation. 


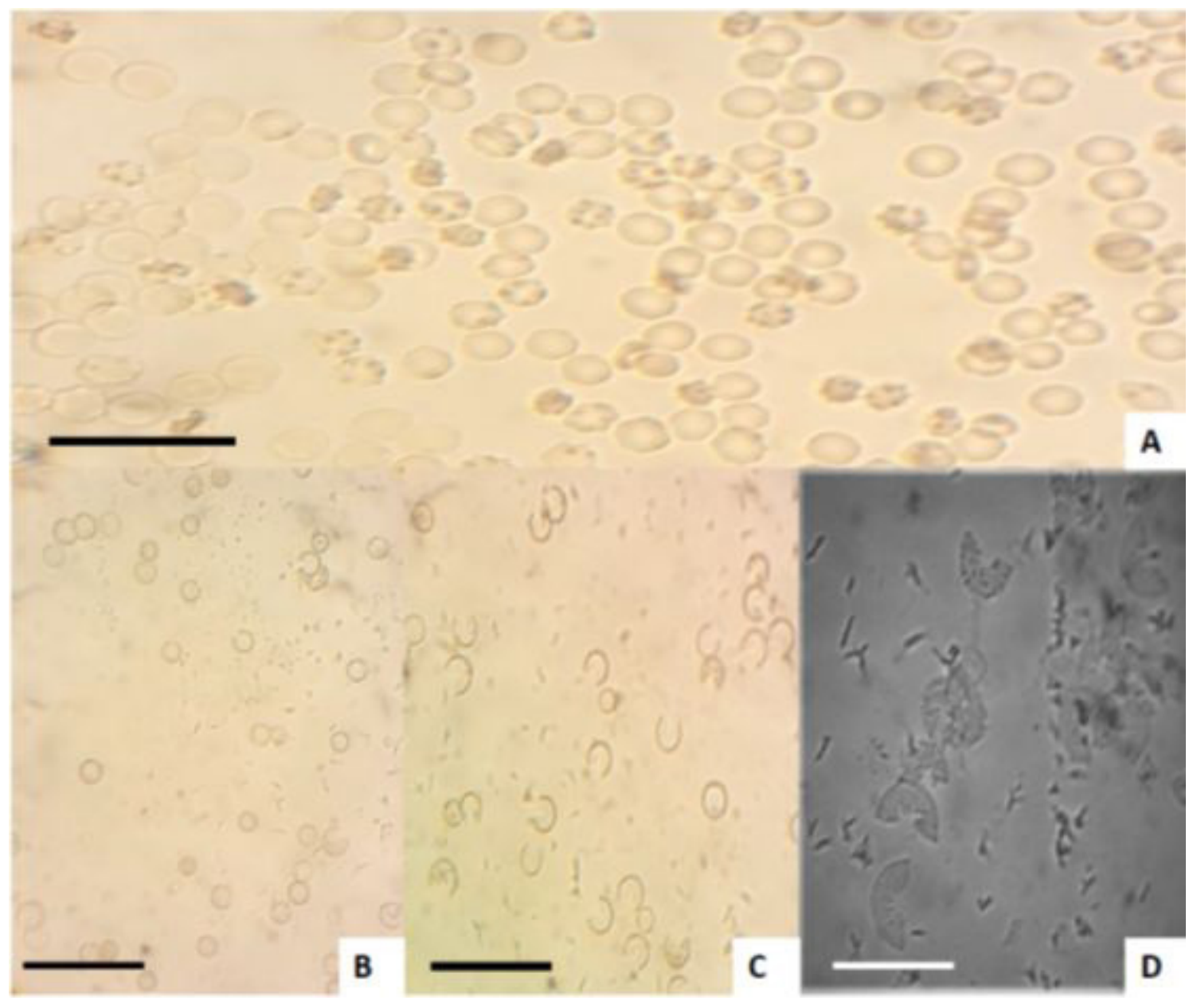

Figure 1. Erythrocyte hemolysis in a 5\% red blood cell suspension by the hydroethanolic extract of A. peregrina stem bark. (A) $5 \%$ suspension of red blood cells; (B) hemolysis after 1 min of reaction; (C) advanced hemolysis after 5 min; and (D) completely hemolyzed red blood cells within 10 min of reaction. Bars: At (A) 1.000×; (B) 500×; (C) 650×; and (D) 1.800×.

Table 3. Diameter of the inhibitory zone of the hydroethanolic extract of Anadenanthera peregrina stem bark against Staphylococcus aureus (ATCC 25923) and Escherichia coli (ATCC 25922).

\begin{tabular}{|c|c|c|c|c|c|}
\hline \multirow{2}{*}{ Strain } & \multicolumn{3}{|c|}{ A. peregrina extract concentration } & \multirow{2}{*}{$\mathbf{C}+$} & \multirow{2}{*}{ C - } \\
\hline & $50 \mu \mathbf{L}$ & $100 \mu \mathbf{L}$ & $200 \mu \mathbf{L}$ & & \\
\hline E. coli & - & - & - & $29 \mathrm{~mm}$ & - \\
\hline S. aureus & $10 \mathrm{~mm}$ & $16 \mathrm{~mm}$ & $20 \mathrm{~mm}$ & $35 \mathrm{~mm}$ & - \\
\hline
\end{tabular}

Positive control $(\mathrm{C}+)=$ meropenem; negative control $(\mathrm{C}-)$ = saline solution .

act on the myocardium to alleviate heart failure and intoxication (Vickery and Vickery, 1981), a beneficial characteristic for medicinal plants.

In the present study, alkaloids, non-reducing sugars, foamed saponins, polysaccharides, purines, steroids, triterpenoids, and sesquiterpenelactones were not detected in A. peregrina stem bark extract. There are numerous factors that influence the production of certain class of compounds by plants, including the seasonality, circadian rhythm, and full development of the plant. Therefore, frequent sample collection in different seasons is necessary
(Gobbo-Neto and Lopes, 2007). It is noteworthy that the alkaloid 5-Hydroxy-N,N-dimethyltryptamine (bufotenine) has been identified in the seeds of $A$. peregrina (Blackledge and Phelan, 2006). Foamed saponins were not present in the extract, and it is possible that during the sample collection period, this class of compounds was produced in minimal detectable quantities or was not produced (Ndamba et al., 1994).

Here, we observed erythrocyte hemolysis at different time points, suggesting that the extract is toxic to the hematopoietic system. The interaction of the extract 

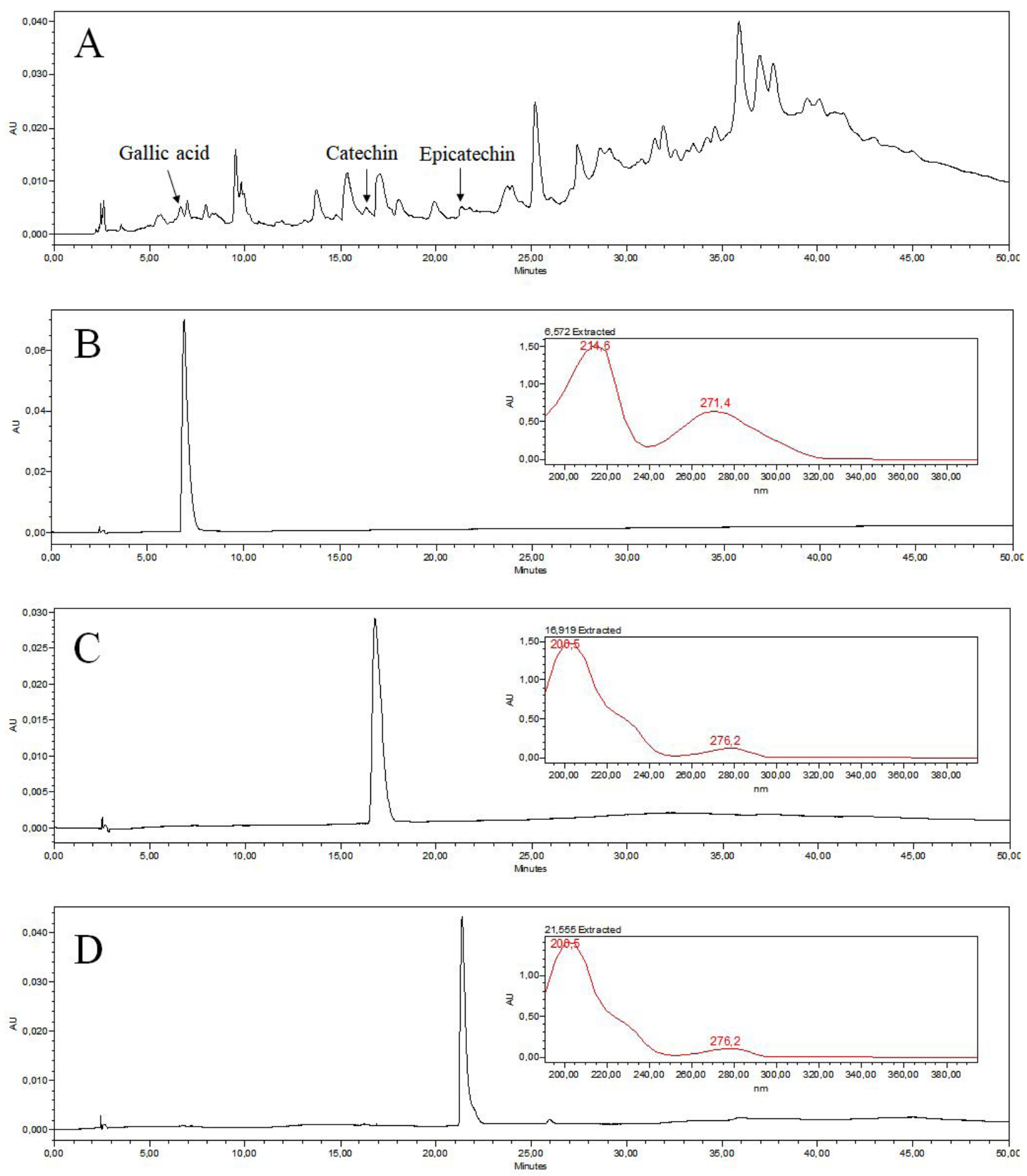

Figure 2. HPLC-PDA chromatographic profiles $(\lambda=254 \mathrm{~nm}$ ) of: (A) sample extract; (B) gallic acid standard; (C) catechin standard; and (D) epicatechin standard, followed by UV spectra (190-400 nm).

with the erythrocyte membrane constituent sterols leads to the formation of pores in the membrane causing hemolysis, resulting in hemoglobin dispersion to the external environment (Sousa et al., 2018); furthermore, the platelets aggregated in small clusters. Further studies should be performed to evaluate the cytotoxic action of the stem bark extract of $A$. peregrina with respect to its action on platelets.

Starch and mucilage are the well-known polysaccharides with phytotherapeutic action against pneumological inflammation (Menezes Filho and Castro, 2018). In the present study, polysaccharides were not observed, although A. peregrina extract has been reported to exhibit this function (Souza et al., 2016).

The absence of purine compounds, steroids, triterpenoids, and sesquiterpene lactones in the stem bark extract of $A$. peregrine reinforces seasonal variations in the production of secondary metabolites (Gobbo-Neto and Lopes, 2007). Other important factors associated with the production of secondary metabolites are age, development, and different organs of plants, influencing the content and relative proportion of components in 
the extract (Hendricks et al., 1997). Purine compounds with at least one structural nitrogen $(\mathrm{N})$ atom have potential use in the production of new drugs, owing to their antiangiogenic and cytotoxic activities; thus, these compounds are important to the pharmaceutical and agricultural industries (Palkar et al., 2015). Furthermore, purines are associated with the wound-healing property of $A$. peregrina extract, favoring angiogenesis. The potential agronomic benefits of the extract are associated with steroidal and triterpene compounds, which are involved in pollen tube growth, internode elongation, and plant growth regulator production (Carvalho et al., 2015).

In the presented study, organic acids were detected in the extract; they, especially malate, citrate, and oxalate, play a role in the tolerance mechanisms of plants to aluminum silicates (Hartwig et al., 2007). Citrate is the most common organic acid in plants; it is a tricarboxylated anion that can form chelates with $\mathrm{Al}_{3}$ with stable bonds (Jian Zheng et al., 1998; Piñeros et al., 2002).

In the present study, the extract was positive for reducing sugars and coumarins. Glucose and fructose are the reducing sugars that are present in diverse plant organs. Glucose acts synergistically on the central nervous system supplying energy and on the gastrointestinal system. Fructose acts as a source of energy to the musculoskeletal system (Barreiros et al., 2005; Araújo and Martel 2009). Among the coumarins, phytoalexins exhibit phytopathogenic activity as a fungicide. Phytoalexins act on cytoplasmic granulation systems, disorganize cellular content, cause plasma membrane disruption, and inhibit fungal enzymes, and thereby reduce and inhibit mycelial growth (Schwan-Estrada et al., 2000); these findings validate their antimicrobial use (Souza et al., 2016).

In the present study, we detected tannins in the extract. Tannins are categorized as flavanones, procyanidins, and condensed and hydrolysable tannins. Condensed tannins include true non-hydrolysable tannin compounds, and they are more resistant to fragmentation and are associated with flavonoid pigments, with the flavan-3-ol polymeric structure. Tannins are responsible for the reddish coloration of the stem bark (SBFGONOSIA, 2009). Tannins are known for their medicinal properties, including antioxidant and bactericidal activities (Ogawa and Yazaki, 2018; Cruz et al., 2020).

Hydrolyzable tannins such as gallotannins (metadigalloyl groups > penta- 0 -galloyl- $\beta$ - $D$-glucose $(P G G$ ) and ellagitannins (hexahydroxydiphenoyl (HHDP) > strictinin: $\mathrm{R} 1=(\beta)-\mathrm{OG}, \mathrm{R} 2=\mathrm{R} 3=\mathrm{H})$ are chemically composed of several molecules of phenolic acids, such gallic and ellagic acids, joined with a central glucose structure. The ester bonds are easily susceptible to hydrolysis by acids or enzymes, and in a solution, hydrolyzable tannins present a bluish color with ferric chloride, like gallic acid (Fernandes et al., 2018; Dai et al., 2020).

During the rainy season, grasses produce higher quantities of tannins, which are considered an antinutritional factor, reducing the consumption of grasses by ruminants, causing nutritional deficit (Nepomuceno et al., 2013). The ingestion of large amounts of tannin compounds can interfere with the digestibility, absorption, and bioavailability of nutrients (Lamy et al., 2011). However, in granular sorghum under short and medium cycle intercropping, condensed tannins improved grain yield, ranging from 1.285 to $8.710 \mathrm{~kg} \mathrm{ha}^{-1}$, dietary protein content, growth rate, fertility, and animal welfare (De Souza et al., 2019; Cuitiño and Vera, 2016).

Flavonoids are secondary metabolites known for their allelopathic effect in plants with various biological properties, especially, anti-inflammatory (Serafini et al., 2010) and antioxidant activities (Khater et al., 2019). In the present study, flavonoids were detected in the extract, validating its medicinal use. Some characteristic flavonoid phytoalexins identified in sorghum (3-deoxiantocyanidine flavonoids) include the following: luteolinidine, 5-methoxyluteolinidine, apigeninidin, and arabinosil-5O-apigeninidin caffeic acid ester (Nicholson et al., 1987). In soybean, the phytoalexin glyceollin (pterocarpanoid) has been identified (Burden and Bailey, 1975).

In the present study, catechins were detected in the extract. Catechins include a diverse group of allelopathic compounds involved in plant-plant interaction, and they are widely used as an insecticide and a natural herbicide. These findings highlight the potential use of the extract as a natural defensive agent (Rabaioli and Silva, 2016).

Here, benzoquinone and depside and depsidone derivatives were also detected in the extract. The p-benzoquinone sorgoleone acts as a natural herbicide, via allelopathic effects on sorghum (Carvalho et al., 2015). This compound acts as a potent inhibitor of mitochondrial respiration and photosynthesis, via its action in the electron transport chain of photosystem II, competing for the same site of action of synthetic herbicides (atrazine and diuron) (Gonzalez et al., 1997). Depsides are polyketides and are produced via the biosynthetic reaction of orselinic acid synthase, where chain cyclization occurs in the formation of this acid. The derivatives of this compound have potential anticancer and anti-inflammatory activities (Kamiya et al., 2018).

In the present study, the test for phenols was positive and the total amount was evaluated in GAE. Phenolic compounds are important for the therapeutic properties of plants. The relationship between polyphenols and human health has been explored with an emphasis on cardiovascular diseases and metabolic syndrome, highlighting the relevance of these bioactive compounds (Durazzo et al., 2019). Phenolic compounds can alleviate the deleterious effects of free radicals acquired or internally produced in an organism. Several plant phenols effectively protect cells under oxidative stress. Studies have explored the potential of phenolic compounds and its derivatives in the treatment of inflammatory diseases, via autophagy mechanisms (Zenkov et al., 2016) and antimicrobial activity (Pinheiro et al., 2018).

In the present study, gallic acid, catechin, and epicatechin were detected in the extract by HPLC fingerprinting; they are common precursors of tannins. Thus, it is possible that the extract contained hydrolyzable tannins (gallotannins) and condensed tannins (catechin tannins and proanthocyanidins). These findings corroborated with those of the preliminary phytochemical screening, contributing to a better understanding of the chemical composition of this species. According to Monteiro et al. (2005), Azêvedo et al. (2017), and Dai et al. (2020), the 
proportion of hydrolyzable and condensed tannins varies considerably, irrespective of whether both groups are present in the same plant; their content is influenced by natural factors (such as rain, soil, soil nutrition, and solar radiation), as well as by factors between species of the same group, genus, or family.

The qualitative analysis by HPLC of $A$. colubrina aerial parts indicated the presence of quercetin and low levels of gallic acid, catechin, and p-coumaric acid (Araújo et al., 2019). Gallic acid, catechin, and epicatechin have been shown to possess a wide variety of pharmacological activities, including antimicrobial, anti-inflammatory, and antioxidant activities (Abdulah et al., 2017; Kahkeshani et al., 2019; Pedro et al., 2019; ), elucidating the therapeutic uses of $A$. peregrina.

Although other compounds evaluated were not found in the extract in the present study, it does not necessarily indicate that they are not produced by this species, as several factors may be involved in the biosynthesis of secondary metabolites, including environmental and genetic factors (Gobbo-Neto and Lopes, 2007; Pavarini et al., 2012). Further studies may highlight the potential of A. peregrina stem bark as an alternative source of these compounds, which may also be used as chemical markers of the species for quality control.

In the present study, the DPPH assay revealed the antioxidant activity of the hydroethanolic extract of A. peregrina stem bark. Although the $\mathrm{IC}_{50}$ value of BHT was lower than that of the extract, the results showed that the plant possesses antioxidant activity. The chemical compounds produced by plants can be altered by several abiotic factors, which interfere in the expression of allelopathic compounds (Pilatti et al., 2019). It is suggested that the antioxidant activity may be related to the presence of phenolic compounds, especially tannins that have antioxidant activity, and they were identified in the present study. Moreover, the dark color of the extract might be due to the presence of high levels of chlorophyll A and B pigments, and these pigments possibly masked the colorimetric reaction to reduce the purple coloration of the radical.

Mota et al.(2017) evaluated the hydroethanolic 50\% (v/v) extract of $A$. peregrina bark. They reported a high content of total phenolic compounds (583 $\mathrm{mg}$ of GAE g-1 extract) and antioxidant activity of moderate intensity with an average $\mathrm{IC}_{50}$ value of $13 \mu \mathrm{g} \mathrm{mL} \mathrm{m}^{-1}$ compared with $2 \mathrm{mg} \mathrm{mL}^{-1}$ for Trolox. Furthermore, the Trolox equivalent antioxidant capacity was $237.6 \mathrm{mg}$ Trolox $\mathrm{g}^{-1}$. The phenol content in the bark extracts is highly variable between species, and the phenol content reported by Santos et al. (2012) in the bark extracts of Eucalyptus grandis (386 mg of GAE g-1), E. urograndis (347 $\mathrm{mg}$ of GAE g ${ }^{-1}$ ), and E. maidenii (204 mg of GAE $\mathrm{g}^{-1}$ ) was lower than that reported on the bark of A. peregrina by Mota et al. (2017). Moreover, the methanolic extract obtained from eucalyptus barks is reported to exhibit antioxidant activity, validated by the presence of phenolic compounds and flavonoids (Mishra et al., 2010; Srivastava and Vankar, 2012). Just like as eucalyptus barks, A. peregrina barks are a source of polar extracts due to the presence of tannins and other phenolic compounds and can be used in the pharmaceutical sectors due to their antioxidant potential (Sartori et al., 2013).

Other studies on Anadenanthera species revealed their antimicrobial activity against $S$. aureus and E. coli (Araújo et al., 2015), potentiated action of neomycin and amikacin (Barreto et al., 2016), of cephalexin related to the amount of bark tannins (Araújo et al., 2018) and synergistic when combined with fluconazole (Nunes et al., 2015). In addition, Anadenanthera species have been reported to possess antifungal potential (Lima et al., 2014), inhibit biofilms (Trentin et al., 2013), and assist in pain management (Santos et al., 2013; Damascena et al., 2014). Angico hydroalcoholic extract (Anadenanthera colubrina var. cebil) has been reported to accelerate wound healing in rats. Furthermore, reducing sugars $(++)$, flavonoids (quercetins) $(+)$, condensed proanthocyanidins $(+++)$, leucoanthocyanidins $(++)$, saponins (saponosides) $(+)$, and triterpenes and steroids $(+)$ were found in the extract (Pessoa et al., 2012, 2015).

In conclusion, the phytochemical analysis of the hydroethanolic stem bark extract of $A$. peregrina showed the presence of a wide variety of chemical compounds with importance in the pharmaceutical, food, and agricultural fields. The HPLC fingerprinting analysis revealed the presence of gallic acid, catechin, and epicatechin in the extract. The extract showed hemolytic action, necessitating further toxicological assessment. Furthermore, the extract showed antibacterial and antioxidant activities. The results contribute to a better understanding of the chemical composition of $A$. peregrina stem bark extract and further strengthen its application in traditional medicine practices.

\section{References}

ABDULAH, R., SURADJI, E.W., SUBARNAS, A., SUPRATMAN, U., SUGIJANTO, M., DIANTINI, A., LESTARI, K., BARLIANA, M.I., KAWAZU, S. and KOYAMA, H., 2017. Catechin isolated from Garcinia celebica leaves inhibit Plasmodium falciparum growth through the induction of oxidative stress. Pharmacognosy Magazine, vol. 13, no. 2, suppl. 2, pp. 301-305. http://dx.doi. org/10.4103/pm.pm_571_16. PMid:28808396.

ALMEIDA, N.F., MORI, F.A., GOULART, S.L. and MENDES, L.M., 2010. Estudos da reatividade de taninos de folhas e cascas de barbatimão Stryphnodendron adstringens (Mart) Coville. Scientia Forestalis, vol. 38, pp. 101-108.

ALMOHAWES, Z.N. and ALRUHAIMI, H.S., 2020. Effect of Lavandula dentata extract on ovalbumin-induced asthma in male guinea pigs. Brazilian Journal of Biology = Revista Brasileira de Biologia, vol. 80, no. 1, pp. 87-96. http://dx.doi.org/10.1590/15196984.191485. PMid:31017237.

ARAÚJO, D.R.C., DA SILVA, T.D., HARAND, W., LIMA, C.S.A., NETO, J.P.F., RAMOS, B.A., ROCHA, T.A., ALVES, H.S., DE SOUSA, R.S., OLIVEIRA, A.P., DA SILVA, L.C.N. and CORREA, M.T.S., 2019. Bioguided purification of active compounds from leaves of Anadenanthera colubrina var. cebil (Griseb.) Altschul. Biomolecules, vol. 9, no. 10, pp. 1-14. http://dx.doi.org/10.3390/ biom9100590. PMid:31597408.

ARAÚJO, E.R.D., OLIVEIRA, D.C., SOARES, T.C., LANGASSNER, S.M.Z., TAVARES, J.C.M. and SILVA, D.G.K.C., 2015. Avaliação do potencial antimicrobiano de extrato hidroalcoólico e aquoso da espécie Anadenanthera colubrina frente à bactérias gram negativa e 
gram positiva. Biota Amazônia, vol. 5, no. 3, pp. 66-71. http:// dx.doi.org/10.18561/2179-5746/biotaamazonia.v5n3p66-71.

ARAÚJO,J.R. and MARTEL, F., 2009. Regulação da absorção intestinal de glicose: uma breve revisão. Arquivos de Medicina, vol. 23, no. 2, pp. 35-43.

ARAÚJO, J.S.C., DE CASTILHO, A.R.F., LIRA, A.B., PEREIRA, A.V., AZEVÊDO, T.K.B., COSTA, E.M.M.B., PEREIRA, M.S.V., PESSÔA, H.L.F. and PEREIRA, J.V., 2018. Antibacterial activity against cariogenic bacteria and cytotoxic and genotoxic potential of Anacardium occidentale L. and Anadenanthera macrocarpa (Benth.) Brenan extracts. Archives of Oral Biology, vol. 85, pp. 113-119. http://dx.doi.org/10.1016/j.archoralbio.2017.10.008. PMid:29054025.

ARRUDA, H.S., PEREIRA, G.A., MORAIS, D.R., EBERLIN, M.N. and PASTORE, G.M., 2018. Determination of free, esterified, glycosylated and insoluble-bound phenolics composition in the edible part of araticum fruit (Annona crassiflora Mart.) and its by-products by HPLC-ESI-MS/MS. Food Chemistry, vol. 245 , pp. 738-749. http://dx.doi.org/10.1016/j.foodchem.2017.11.120. PMid:29287435.

AZEVÊDO, T.K.B., PAES, J.B., CALEGARI, L. and SANTANA, G.M., 2017. Teor de Taninos condensados presente na casca de juremapreta (Mimosa tenuiflora) em função das fenofases. Floresta e Ambiente, vol. 24, no. 0, pp. 1-7. http://dx.doi.org/10.1590/21798087.026613

BAILÃO, E.F.L.C., DEVILLA, I.A., DA CONCEIÇÃO, E.C. and BORGES, L.L., 2015. Bioactive Compounds Found in Brazilian Cerrado Fruits. International Journal of Molecular Sciences, vol. 16, no. 10, pp. 23760-23783. http://dx.doi.org/10.3390/ijms161023760. PMid:26473827.

BARREIROS, C.R., BOSSOLAN, G. and TRINDADE, P.E.C., 2005. Frutose em humanos: efeitos metabólicos, utilização clínica e erros inatos associados. Revista de Nutrição, vol. 18, no. 3, pp. 377 389. http://dx.doi.org/10.1590/S1415-52732005000300010.

BARRETO, H.M., COELHO, K.M., FERREIRA, J.H., SANTOS, B.H., ABREU, A.P.L., COUTINHO, H.D., SILVA, R.A.C., SOUSA, T.O., CITÓ, A.M.G.L. and LOPES, J.A.D., 2016. Enhancement of the antibiotic activity of aminoglycosides by extracts from Anadenanthera colubrine (Vell.) Brenan var. cebil against multi-drug resistant bacteria. Natural Product Research, vol. 30, no. 11, pp. 1289-1292. http:// dx.doi.org/10.1080/14786419.2015.1049177. PMid:26158209.

BARTH, E.F., PINTO, L.S., DILELI, P., BIAVATTI, D.C., SILVA, Y.L., BORTOLUCCI, W., GAZIM, Z.C., TAKEMURA, O.S., ROMAGNOLO, M.B. and LAVERDE-JÚNIOR, A., 2018. Biological screening of extracts from leaf and stem bark of Croton floribundus Spreng. (Euphorbiaceae). Brazilian Journal of Biology = Revista Brasileira de Biologia, vol. 78, no. 4, pp. 601-608. http://dx.doi. org/10.1590/1519-6984.166522. PMid:29319750.

BLACKLEDGE, R.D. and PHELAN, C.P., 2006. Identification of bufotenine in yopo seeds via GC/IRD. Microgram Journal, vol. 4, no. 1-4, pp. 3-11.

BRASIL. Agência Nacional de Vigilância Sanitária - ANVISA, 2010 [viewed 20 February 2020]. Farmacopeia brasileira. 5. ed. Brasília. [online]. Available from: http://portal.anvisa.gov.br/ documents/33832/260079/5\%C2\%AA+edi\%C3\%A7\%C3\%A30++Volume+1/4c530f86-fe83-4c4a-b907-6a96b5c2d2fc

BRASIL. Ministério do Meio Ambiente - MMA, 2019 [viewed 20 February 2020]. O bioma Cerrado [online]. Brasília. Available from: https://www.mma.gov.br/biomas/cerrado

BURDEN, R.J. and BAILEY, J.A., 1975. Structure of the phytoalexin from soybean. Phytochemistry, vol. 14, no. 5-6, pp. 1389-1390. http://dx.doi.org/10.1016/S0031-9422(00)98633-3.
CARVALHO, P.E.R., 2003. Espécies arbóreas brasileiras. Brasília: Embrapa Informação Tecnológica, vol. 1, 1039 p.

CARVALHO, W.P., CARVALHO, G.J., CARDOSO, M.G., ANDRADE, M.A., ANDRADE, J., TEIXEIRA, M.L. and SILVA, L.F., 2015. Prospecção fitoquímica de adubos verdes em cultivo exclusivo e consorciado. Cultura Agronômica, vol. 24, no. 3, pp. 257-274.

CRUZ, J.A., SILVA, A.B., RAMIN, B.B.S., SOUZA, P.R., POPAT, K.C., ZOLA, R.S., KIPPER, M.J. and MARTINS, A.F., 2020. Poly(vinyl alcohol)/ cationic tannin blend films with antioxidant and antimicrobial activities. Materials Science and Engineering C, vol. 107, pp. 110357. http://dx.doi.org/10.1016/j.msec.2019.110357. PMid:31761187.

CUITIÑO, M.J. and VERA, M., 2016. Efecto de los taninos condensados em el rendimiento de sorgo granífero. Revista INIA, vol. 44, pp. 20-24.

DAI, X., LIU, Y., ZHUANG, J., YAO, S., LIU, L., JIANG, X., ZHOU, K., WANG, Y., XIE, D., BENNETZEN, J.L., GAO, L. and XIA, T., 2020. Discovery and characterization of tannase genes in plants: roles in hidrolysis of tannins. The New Phytologist, vol. 226, no. 4, pp. 1104-1116. http://dx.doi.org/10.1111/nph.16425. PMid:32061142.

DAMASCENA, N.P., SOUZA, M.T., ALMEIDA, A.F., CUNHA, R.S., DAMASCENA, N.P., CURVELLO, R.L., LIMA, A.C., ALIMEIDA, E.C., SANTOS, C.C., DIAS, A.S., PAIXÃO, M.S., SOUZA, L.M., QUINTAS JÚNIOR, L.J., ESTEVAM, C.S. and ARAUJO, B.S., 2014. Antioxidant and orofacial anti-nociceptive activities of the stem bark aqueous extract of Anadenanthera colubrina (Velloso) Brenan (Fabaceae). Natural Product Research, vol. 28, no. 10, pp. 753-756. http:// dx.doi.org/10.1080/14786419.2013.877902. PMid:24438027.

DURAZZO, A., LUCARINI, M., SOUTO, E.B., CICALA, C., CAIAZZO, E., IZZO, A.A., NOVELLINO, E. and SANTINI, A., 2019. Polyphenols: a concise overview on the chemistry, occurrence, and human health. Phytotherapy Research, vol. 33, no. 9, pp. 2221-2243. http://dx.doi.org/10.1002/ptr.6419. PMid:31359516.

DUTRA, R.C., CAMPOS, M.M., SANTOS, A.R. and CALIXTO, J.B., 2016. Medicinal plants in Brazil: pharmacological studies, drug discovery, challenges and perspectives. Pharmacological Research, vol. 112, pp. 4-29. http://dx.doi.org/10.1016/j.phrs.2016.01.021. PMid:26812486.

EMRE, İ., KURŞAT, M., YILMAZ, Ö. and ERECEVIT, P., 2020. Chemical compositions, radical scavenging capacities and antimicrobial activities in seeds of Satureja hortensis L. and Mentha spicata L. subsp. spicata from Turkey. Brazilian Journal of Biology = Revista Brasileira de Biologia. http://dx.doi.org/10.1590/15196984.224654. PMid:32401852.

FERNANDES, L., CASAL, S., PEREIRA, J.A., SARAIVA, J.A. and RAMALHOSA, E., 2018. Effects of different drying methods on the bioactive compounds and antioxidant properties of edible Centaurea (Centaurea cyanus) petals. Brazilian Journal of Food Technology, vol. 21, no. 0, pp. 1-10. http://dx.doi. org/10.1590/1981-6723.21117.

GAMA, A.D.S., PAULA, M., SILVA, R.R.V., FERREIRA JÚNIOR, W.S. and MEDEIROS, P.M.D., 2018. Exotic species as models to understand biocultural adaptation: challenges to mainstream views of human-nature relations. PLoS One, vol. 13, no. 4, e0196091. http://dx.doi.org/10.1371/journal.pone.0196091. PMid:29708981.

GOBBO-NETO, L. and LOPES, N.P., 2007. Plantas medicinais: fatores de influência no conteúdo de metabólitos secundários. Química Nova, vol. 30, no. 2, pp. 374-381. http://dx.doi.org/10.1590/ S0100-40422007000200026.

GONZALEZ, V.M., KAZIMIR, J., NIMBAL, C., WESTON, L. and CHENIAE, G.M., 1997. Inhibition of a photosystem II eletron transfer reaction by the natural product sorgoleone. Journal of Agricultural and Food Chemistry, vol. 45, no. 4, pp. 1415-1421. http://dx.doi.org/10.1021/jf960733w. 
HARTWIG, I., OLIVEIRA, A.C., CARVALHO, F.I.F., BERTAN, I., SILVA, J.A.G., SCHMIDT, D.A.M., VALÉRIO, I.P., MAIA, L.C., FONSECA, D.A.R. and REIS, C.E.S., 2007. Mecanismos associados à tolerância ao alumínio em plantas. Semina: Ciências Agrárias, vol. 28, no. 2, pp. 219-228. http://dx.doi.org/10.5433/16790359.2007v28n2p219.

HENDRICKS, H., ANDERSON-WILDEBOER, Y., ENGELS, G., BOS, R. and WOERDENBAG, H.J., 1997. The content of parthenolide and its yield per plant during the growth of Tanacetum parthenium. Planta Medica, vol. 63, no. 4, pp. 356-359. http://dx.doi. org/10.1055/s-2006-957700. PMid:17252395.

JIAN ZHENG, S., JIAN FENG, M. and MATSUMOTO, H., 1998. High aluminum resistance in buckwheat: I. Al-induced specific secretion of oxalic acid from root tips. Plant Physiology, vol. 117, no. 3, pp. 745-751. http://dx.doi.org/10.1104/pp.117.3.745. PMid:9662517.

KAHKESHANI, N., FARZAEI, F., FOTOUHI, M., ALAVI, S.S.H., BAHRAMSOLTANI, R., NASERI, R., MOMTAZ, S., ABBASABADI, Z., RAHIMI, R., FARZAEI, M.H. and BISHAYEE, A., 2019. Pharmacological effects of gallic acid in health and diseases: a mechanistic review. Iranian Journal of Basic Medical Sciences. vol. 22, no. 3, pp. 225-237. http://dx.doi.org/10.22038/ ijbms.2019.32806.7897. PMid:31156781.

KAMIYA, T., TANIMOTO, Y., FUJII, N., NEGISHI, T., SUZUKI, T., HATANO, T. and ARIMOTO-KOBAYASHI, S., 2018. 2,6-Dimethoxy-1,4benzoquinone, isolation and identification of anti-carcinogenic, anti-mutagenic and anti-inflammatory component from the juice of Vitis coignetiae. Food and Chemical Toxicology, vol. 122, pp. 172-180. http://dx.doi.org/10.1016/j.fct.2018.10.028. PMid:30316843.

KHATER, M., RAVISHANKAR, D., GRECO, F. and OSBORN, H.M., 2019. Metal complexes of flavonoids: their synthesis, characterization and enhanced antioxidant and anticancer activities. Future Medicinal Chemistry, vol. 11, no. 21, pp. 2845-2867. http://dx.doi. org/10.4155/fmc-2019-0237. PMid:31722558.

KLOSS, L.C., ALBINO, A.M., SOUZA, R.G. and LIMA, R.A., 2016. Identification of classes of secondary metabolities of the ethanol extract of Piper umbellatum L. (Piperaceae). South American Journal of Basic Education. Technical and Technological, vol. 3 , no. 2, pp. $118-128$

LAMY, E., RAWEL, H., SCHWEIGERT, F.J., CAPELA E SILVA, F., FERREIRA, A., COSTA, A.R., ANTUNES, C., ALMEIDA, A.M., COELHO, A.V. and SALES-BAPTISTA, E., 2011. The effect of tannins on Mediterranean ruminant ingestive behaviour: the role of the oral cavity. Molecules, vol. 16, no. 4, pp. 2766-2784. http://dx.doi.org/10.3390/molecules16042766. PMid:21441875.

LIMA, R.D.E.F., ALVES, E.P., ROSALEN, P.L., RUIZ, A.L.T.G., TEIXEIRA DUARTE, M.C., GÓES, V.F.F., MEDEIROS, A.C.D., PEREIRA, J.V., GODOY, G.P. and COSTA, E.M.M.B., 2014. Antimicrobial and Antiproliferative Potential of Anadenanthera colubrina (Vell.) Brenan. Evidence-Based Complementary and Alternative Medicine, vol. 2014, 802696. http://dx.doi.org/10.1155/2014/802696. PMid:25093029.

LONGHINI, R., RAKSA, S.M., OLIVEIRA, A.C.P., SVIDZINSKI, T.I.E. and FRANCO, S.L., 2007. Obtenção de extratos de própolis sob diferentes condições e avaliação de sua atividade antifúngica. Revista Brasileira de Farmacognosia, vol. 17, no. 3, pp. 388-395. http://dx.doi.org/10.1590/S0102-695X2007000300015.

MARÍN, R.M., GARCÍA, J.C.L., GARCÍA, R.M.B. and ALARCÓN, A.B., 2018. Phytochemical Screening and Isolation of triterpenes and sterols from leaves of Clusia minor L. Revista Cubana de Plantas Medicinales, vol. 23, no. 3, pp. 1-8.

MARTINS, C.M., MORAIS, S.A.L., MARTINS, M.M., CUNHA, L.C.S., SILVA, C.V., MARTINS, C.H.G., LEANDRO, L.F., OLIVEIRA, A.,
AQUINO, F.J.T., NASCIMENTO, E.A. and CHANG, R., 2019. Chemical composition, antifungal, and cytotoxicity Activities of Inga laurina (Sw.) willd leaves. The Scientific World Journal, vol. 2019, pp. 1-12. http://dx.doi.org/10.1155/2019/9423658. PMid:30853865.

MENDONÇA, L.A.B.M., MATIAS, R., ZANELLA, D.F.P., PORTO, K.R.A., GUILHERMINO, J.F., MOREIRA, D.L., ROEL, A.R., POTT, A. and CARVALHO, C.M.E., 2019. Toxicity and phytochemistry of eight species used in the traditional medicine of sul-mato-grossense, Brazil. Brazilian Journal of Biology = Revista Brasileira de Biologia, vol. 80, no. 3, pp. 574-581. http://dx.doi.org/10.1590/15196984.216406. PMid:31644651.

MENEZES FILHO, A.C.P. and CASTRO, C.F.S., 2018. Phytochemical analysis of jatobá-do-cerrado fruits (Hymenaea stigonocarpa Mart. ex Hayne) and murici-bravo (Byrsonima coccolobifolia Kunth.). Global Science and Technology, vol. 11, no. 3, pp. 241-255.

MENEZES FILHO, A.C.P., OLIVEIRA-FILHO, J.G., CHRISTOFOLI, M. and CASTRO, C.F.S., 2018. Antioxidant activity, total phenolic content, carotenoids and provitamin A in vegetables extracts from Cerrado goiano. Uniciências, vol. 22, no. 1, pp. 28-32. http:// dx.doi.org/10.17921/1415-5141.2018v22n1p28-32.

MISHRA, A.K., SAHU, N., MISHRA, A., GHOSH, A.K., JHA, S. and CHATTOPADHYAY, P., 2010. Phytochemical screening and antioxidant activity of essential oil of eucalyptus leaf. Pharmacognosy Journal, vol. 2, no. 16, pp. 21-24. http://dx.doi. org/10.1016/S0975-3575(10)80045-8.

MONTEIRO, J.M., ALBUQUERQUE, U.P., ARAÚJO, E.L. and AMORIM, E.L.C., 2005. Taninos: uma abordagem da quimica à ecologia. Química Nova, vol. 28, no. 5, pp. 892-896. http://dx.doi. org/10.1590/S0100-40422005000500029.

MOREIRA, L.N., SILVA, G.C., CÂMARA, D.V., PÁDUA, R.M., LEMOS, V.S., BRAGA, F.C. and CORTES, S.F., 2019. The Cyclitol L-(+)bornesitol as an active marker for the cardiovascular activity of the brazilian medicinal plant Hancornia speciosa. Biological E'Pharmaceutical Bulletin, vol. 42, no. 12, pp. 2076-2082. http:// dx.doi.org/10.1248/bpb.b19-00601. PMid:31787722.

MORIM, M.P., 2015 [viewed 20 February 2020]. Anadenanthera. In: JARDIM BOTÂNICO DO RIO DE JANEIRO - JBRJ. Lista de espécies da flora do Brasil [online]. Rio de Janeiro: JBRJ. Available from: http://floradobrasil.jbrj.gov.br/jabot/floradobrasil/FB22782

MOTA, G.S., SARTORI, C.J., MIRANDA, I., QUILHÓ, T., MORI, F.A. and PEREIRA, H., 2017. Bark anatomy, chemical composition and ethanol-water extract composition of Anadenanthera peregrina and Anadenanthera colubrina. PLoS One, vol. 12, no. 12, pp. e0189263. http://dx.doi.org/10.1371/journal.pone.0189263. PMid:29281656.

NASCIMENTO-SILVA, N.R.R.D. and NAVES, M.M.V., 2019. Potential of whole pequi (Caryocar spp.) fruit-pulp, almond, oil, and shell-as a medicinal food. Journal of Medicinal Food, vol. 22, no. 9, pp. 952-962. http://dx.doi.org/10.1089/jmf.2018.0149. PMid:31074677.

NDAMBA, J., LEMMICH, E. and MøLGAARD, P., 1994. Investigation of the diurnal, ontogenetic and seasonal variation in the Molluscicidal saponin content of Phytolacca dodecandra aqueous berry extracts. Phytochemistry, vol. 35, no. 1, pp. 95-99. http:// dx.doi.org/10.1016/S0031-9422(00)90515-6. PMid:7764378.

NEPOMUCENO, D.D., ALMEIDA, C.C.C., CARVALHO, M.G., FERNANDES, R.D. and CATUNDA JÚNIOR, F.E., 2013. Classes of secondary metabolites identified in tree legume species. Revista Brasileira de Zootecnia, vol. 42, no. 10, pp. 700-705. http://dx.doi.org/10.1590/ S1516-35982013001000002.

NICHOLSON, R.L., KOLLIPARA, S.S., VINCENT, J.R., LYONS, P.C. and CADENA-GOMEZ, G., 1987. Phytoalexin synthesis by the 
sorghum mesocotyl in responce to infection by pathogenic and nonpathogenic fungi. Proceedings of the National Academy of Sciences of the United States of America, vol. 84, no. 16, pp. 5520-5524. http://dx.doi.org/10.1073/pnas.84.16.5520. PMid:16593867.

NUNES, L.E., VIANA, A.P.P., ROCHA, W.R.V., CUNHA, V.D.S., CATÃO, R.M.R. and COSTA, E.M.M.B., 2015. In vitro evaluation of antifungal activity and interactive effect of Anadenanthera colubrina (Benth). African Journal of Microbiological Research, vol. 9, no. 36, pp. 2006-2012. http://dx.doi.org/10.5897/ AJMR2015.7505.

OGAWA, S. and YAZAKI, Y., 2018. Tannins from Acacia mearnsii De Wild. Bark: Tannin determination and biological activities. Molecules, vol. 23, no. 4, pp. 1-18. http://dx.doi.org/10.3390/ molecules23040837. PMid:29621196.

PACHECO, L.A., ETHUR, E.M., SHEIBEL, T., BUHL, B., WEBER, A.C., KAUFFMANN, C., MARCHI, M.I., FREITAS, E.M. and HOEHNE, L., 2020. Chemical characterization and antimicrobial activity of Campomanesia aurea against three strains of Listeria monocytogenes. Brazilian Journal of Biology = Revista Brasileira de Biologia. In press. http://dx.doi.org/10.1590/1519-6984.219889. PMid:32130285.

PALKAR, M.B., RANE, R.A., THAPLIYAL, N., SHAIKH, M.S., ALWAN, W.S., JAIN, K.S., KARUNANIDHI, S., PATEL, H.M., HAMPANNAVAR, G.A. and KARPOORMATH, R., 2015. An insight into purine, tyrosine and tryptophan derived marine antineoplastic alkaloids. Anti-cancer Agents in Medicinal Chemistry, vol. 15, no. 8, pp. 947-954. http://dx.doi.org/10.2174/187152061566615010114 3520. PMid:25553433.

PANDINI, J.A., PINTO, F.G.S., SCUR, M.C., SANTANA, C.B., COSTA, W.F. and TEMPONI, L.G., 2018. Chemical composition, antimicrobial and antioxidant potential of the essential oil of Guarea kunthiana A. Juss. Brazilian Journal of Biology = Revista Brasileira de Biologia, vol. 78, no. 1, pp. 53-60. http://dx.doi. org/10.1590/1519-6984.04116. PMid:28793029.

PAVARINI, D.P., PAVARINI, S.P., NIEHUES, M. and LOPES, N.P., 2012. Exogenous influences on plant secondary metabolite levels. Animal Feed Science and Technology, vol. 176, no. 1-4, pp. 5-16. http://dx.doi.org/10.1016/j.anifeedsci.2012.07.002

PEDRO, A.C., MACIEL, G.M., RIBEIRO, V.R. and HAMINIUK, C.W.I., 2019. Fundamental and applied aspects of catechins from different sources: a review. International Journal of Food Science E Technology. http://dx.doi.org/10.1111/ijfs.14371.

PEREIRA, L.D., VALLE, K.D., SOUZA, L.K.F., PAIVA, E.F., BOLINA, C.D.C., REIS, E.F., SALAZAR, A.H. and SILVA, D.F.P, 2018. Caracterização de frutos de diferentes espécies de maracujazeiro. Revista Brasileira de Agropecuária Sustentável, vol. 8, no. 2, pp. 1-8. http://dx.doi.org/10.21206/rbas.v8i2.502.

PESSOA, W.S., ESTEVÃO, L.R., SIMÕES, R.S., BARROS, M.E.G., MENDONÇA, F.S., BARATELLA-EVÊNCIO, L. and EVÊNCIO-NETO, J., 2012. Effects of angico extract (Anadenanthera colubrina var. cebil) in cutaneous wound healing in rats. Acta Cirurgica Brasileira, vol. 27, no. 10, pp. 655-670. http://dx.doi.org/10.1590/ S0102-86502012001000001. PMid:23033126.

PESSOA, W.S., ESTEVÃO, L.R.M., SIMÕES, R.S., MENDONÇA, F.S., EVÊNCIO-LUZ, L., BARATELLA-EVÊNCIO, L., FLORENCIO-SILVA, R., SÁ, F.B. and EVÊNCIO-NETO, J., 2015. Fibrogenesis and epithelial coating of skin wounds in rats treated with angico extract (Anadenanthera colubrina var. cebil). Acta Cirurgica Brasileira, vol. 30, no. 5, pp. 353-358. http://dx.doi.org/10.1590/ S0102-865020150050000007. PMid:26016935.

PILATTI, D.M., FORTES, A.M.T., JORGE, T.C.M. and BOIAGO, N.P., 2019. Comparison of the phytochemical profiles of five native plant species in two different forest formations. Brazilian Journal of
Biology = Revista Brasileira de Biologia, vol. 79, no. 2, pp. 233-242. http://dx.doi.org/10.1590/1519-6984.179526. PMid:29924133.

PIÑEROS, M.A., MAGALHAES, J.V., CARVALHO ALVES, V.M. and KOCHIAN, L.V., 2002. The physiology and biophysics of na aluminium tolerance mechanism based on root citrate exudation in maize. Plant Physiology, vol. 129, no. 3, pp. 1194-1206. http:// dx.doi.org/10.1104/pp.002295. PMid:12114573.

PINHEIRO, P.F., MENINI, L.A.P., BERNARDES, P.C., SARAIVA, S.H., CARNEIRO, J.W.M., COSTA, A.V., ARRUDA, T.R., LAGE, M.R., GONÇALVES, P.M., BERNARDES, C.O., ALVARENGA, E.S. and MENINI, L., 2018. Semisynthetic Phenol Derivatives Obtained from Natural Phenols: Antimicrobial Activity and Molecular Properties. Journal of Agricultural and Food Chemistry, vol. 66, no. 1, pp. 323-330. http://dx.doi.org/10.1021/acs.jafc.7b04418. PMid:29286652.

PIO, I.D.S.L., LAVOR, A.L., DAMASCENO, C.M.D., MENEZES, P.M.N., SILVA, F.S. and MAIA, G.L.A., 2019. Traditional knowledge and uses of medicinal plants by the inhabitants of the islands of the São Francisco river, Brazil and preliminary analysis of Rhaphiodon echinus (Lamiaceae). Brazilian Journal of Biology = Revista Brasileira de Biologia, vol. 79, no. 1, pp. 87-99. http:// dx.doi.org/10.1590/1519-6984.177447. PMid:29694558.

PONTES, F.C., ABDALLA, V.C.P., IMATOMI, M., FUENTES, L.F.G. and GUALTIERI, S.C.J., 2019. Antifungal and antioxidant activities of mature leaves of Myrcia splendens (Sw.) DC. Brazilian Journal of Biology = Revista Brasileira de Biologia, vol. 79, no. 1, pp. 127-132. http://dx.doi.org/10.1590/1519-6984.179829. PMid:29742197.

QUEIROZ, J.E., SANTOS, D.M., VILA VERDE, G.M., PAULA, J.R. and AQUINO, G.L.B., 2021. Microwave irradiation to the rapid extraction of Stryphnodendron adstringens (Barbatimão) compounds by statistical planning. Natural Product Research, vol. 35, no. 2, pp. 354-358. http://dx.doi.org/10.1080/147864 19.2019.1628748.

RABAIOLI, V. and SILVA, C.P., 2016. Prospecting of different species of plants with biopesticides action in the agriculture of Mato Grosso do Sul. Ensaios e Ciência: Ciências Biológicas, Agrárias e da Saúde, vol. 20, no. 3, pp. 188-195.

RIBEIRO NETO, J.A., PIMENTA TARÔCO, B.R., BATISTA DOS SANTOS, H., THOMÉ, R.G., WOLFRAM, E. and MACIEL DE A RIBEIRO, R.I., 2020. Using the plants of Brazilian Cerrado for wound healing: from traditional use to scientific approach. Journal of Ethnopharmacology, vol. 260, 112547. http://dx.doi.org/10.1016/j. jep.2020.112547. PMid:31917276.

RIBEIRO, A.O., GOULART, S.L., MORI, F.A. and CASTRO, A.H.F., 2014. Tree crown variation and seasonal in the phenolic compounds content of Stryphnodendron adstringens (Mart) coville leaves. American Journal of Plant Sciences, vol. 5, no. 19, pp. 2904-2912. http://dx.doi.org/10.4236/ajps.2014.519305.

RIBEIRO, V.P., ARRUDA, C., ABD EL-SALAM, M. and BASTOS, J.K., 2018. Brazilian medicinal plants with corroborated antiinflammatory activities: a review. Pharmaceutical Biology, vol. 56, no. 1, pp. 253-268. http://dx.doi.org/10.1080/13880209.201 8.1454480. PMid:29648503.

SANTOS, J.S., MARINHO, R.R., EKUNDI-VALENTIM, E., RODRIGUES, L., YAMAMOTO, M.H., TEIXEIRA, S.A., MUSCARA, M.N., COSTA, S.K. and THOMAZZI, S.M., 2013. Beneficial effects of Anadenanthera colubrina (Vell.) Brenan extract on the inflammatory and nociceptive responses in rodent models. Journal of Ethnopharmacology, vol. 148, no. 1, pp. 218-222. http://dx.doi.org/10.1016/j.jep.2013.04.012.

SANTOS, S., VILLA VERDE, J.J., FREIRE, C.S.R., DOMINGUES, M.R.M., PASCOAL NETO, C. and SILVESTRE, A.D., 2012. Phenolic composition and antioxidante activity of Eucalyptus grandis, E. urograndis (E. grandis $\mathrm{x}$ E. urophylla) and E. maidenii bark 
extracts. Industrial Crops and Products, vol. 39, pp. 120-127. http://dx.doi.org/10.1016/j.indcrop.2012.02.003.

SARTORI, C.J., MOTA, G.S., MIRANDA, I., MORI, F.A. and PEREIRA, H., 2013. Tannin extraction and characterization of polar extracts from the barks of two Eucalyptus urophylla hybrids. BioResources, vol. 13, no. 3, pp. 4820-4831.

SCHWAN-ESTRADA, K.R.F., STANGARLIN, J.R. and CRUZ, M.E.S., 2000. Uso de extratos vegetais no controle de fungos fitopatogênicos. Revista Floresta, vol. 30, no. 12, pp. 129-137. http://dx.doi. org/10.5380/rf.v30i12.2361.

SERAFINI, M., PELUSO, I. and RAGUZZINI, A., 2010. Flavonoids as anti-inflammatory agents. The Proceedings of the Nutrition Society, vol. 69, no. 3, pp. 273-278. http://dx.doi.org/10.1017/ S002966511000162X. PMid:20569521.

SILVA, C.P.D., SOARES-FREITAS, R.A.M., SAMPAIO, G.R., SANTOS, M.C.B., DO NASCIMENTO, T.P., CAMERON, L.C., FERREIRA, M.S.L. and ARÊAS, J.A.G., 2019. Identification and action of phenolic compounds of Jatobá-do-cerrado (Hymenaea stignocarpa Mart.) on $\alpha$-amylase and $\alpha$-glucosidase activities and flour effect on glycemic response and nutritional quality of breads. Food Research International, vol. 116, pp. 1076-1083. http://dx.doi. org/10.1016/j.foodres.2018.09.050. PMid:30716891.

SILVA, D.H.A.D., BARBOSA, H.M., BELTRÃO, R.L.A., SILVA, C.F.O., MOURA, C.A., CASTRO, R.N., ALMEIDA, J.R.G.D.S., GOMES, D.A. and LIRA, E.C., 2020. Hexane fraction from Brazilian Morus nigra leaves improved oral carbohydrate tolerance and inhibits $\alpha$-amylase and $\alpha$-glucosidase activities in diabetic mice. Natural Product Research, vol. 24, pp. 1-4. http://dx.doi.org/10.1080/14 786419.2020.1723087. PMid:32091240.

SILVEIRA, L.M.S., OLEA, R.S.G., MESQUITA, J.S., CRUZ, A.L.N. and MENDES, J.C., 2009. Metodologias de atividade antimicrobiana aplicadas a extratos de plantas: comparação entre duas técnicas de ágar difusão. Revista Brasileira de Farmácia, vol. 90, no. 2, pp. 124-128.

SOCIEDADE BRASILEIRA DE FARMACOGNOSIA - SBFGONOSIA, 2009 [viewed 20 February 2020]. Taninos [online]. Available from: www.sbfgnosia.org.br/Ensino/taninos.html

SOUSA, I.J.O., SILVA, M.C.P., LEOPOLDINO, G.L. and AGOSTINHO, L.S., 2018. Estudo fitoquímico, avaliação da capacidade hemolítica e antimicrobiana de um extrato bruto da casca do caule de Ziziphus joazeiro Mart. (Rhamnaceae). Journal of Biology \& Pharmacy and Agricultural Management, vol. 14, no. 4, pp. 208-225.

SOUZA, A.R., CAVASSAN, O., ALMEIDA, M.V., LEGENDRE, A.O. and BANNACH, G., 2014. Flame retardant properties of the bark powder of Anadenanthera peregrina var. falcata (Benth.) Altschul (angico) studied by coupled thermogravimetry-Fourier transform infrared spectroscopy. Journal of Analytical and Applied Pyrolysis, vol. 106, pp. 187-189. http://dx.doi.org/10.1016/j. jaap.2013.12.010.
SOUZA, C.G., MOURA, A.K.B., SILVA, J.N.P., SOARES, K.O., SILVA, J.V.C. and VASCONCELOS, P.C., 2019. Fatores anti-nutricionais de importância na nutrição animal: composição e função dos compostos secundários. Pubvet, vol. 13, no. 5, pp. 1-19. http:// dx.doi.org/10.31533/pubvet.v13n5a327.1-19.

SOUZA, L.F., DIAS, R.F., GUILHERME, F.A.G. and COELHO, C.P., 2016. Plantas medicinais referenciadas por raizeiros no município de Jataí, estado de Goiás. Revista Brasileira de Plantas Medicinais, vol. 18, no. 2, pp. 451-461. http://dx.doi.org/10.1590/1983084X/15_173.

SRIVASTAVA, J. and VANKAR, P.S., 2012. Principal phenolic phytochemicals and antioxidant property in Eucalyptus bark. Nutrition \& Food Science, vol. 42, no. 6, pp. 412-421. http:// dx.doi.org/10.1108/00346651211277663.

TRENTIN, D.S., SILVA, D.B., AMARAL, M.W., ZIMMER, K.R., SILVA, M.V., LOPES, N.P., GIORDANI, R.B. and MACEDO, A.J., 2013. Tannins possessing bacteriostatic effect impair Pseudomonas aeruginosa adhesion and biofilm formation. PLoS One, vol. 8, no. 6, pp. e66257. http://dx.doi.org/10.1371/journal.pone.0066257. PMid:23776646.

VALE, A.F., FERREIRA, H.H., BENETTI, E.J., REBELO, A.C.S., FIGUEIREDO, A.C.R., BARBOSA, E.C. and SIMÕES, K., 2019. Antioxidant effect the pequi oil (Caryocar brasiliense) on the hepatic tissue of rats trained by exhaustive swimming exercises. Brazilian Journal of Biology = Revista Brasileira de Biologia, vol. 79, no. 2, pp. 257-262. http://dx.doi.org/10.1590/1519-6984.180015. PMid:30088525.

VICKERY, M. and VICKERY, B., 1981. Introduction in secondary plant metabolism. London: The Macmillan Press Ltda. http://dx.doi. org/10.1007/978-1-349-86109-5.

VILA VERDE, G.M., BARROS, D.A., OLIVEIRA, M.S., AQUINO, G.L.B., SANTOS, D.M., DE PAULA, J.R., DIAS, L.D., PIÑEIRO, M. and PEREIRA, M.M., 2018. A green protocol for microwave-assisted extraction of volatile oil terpenes from Pterodon emarginatus Vogel. (Fabaceae). Molecules, vol. 23, no. 3, pp. 1-12. http:// dx.doi.org/10.3390/molecules23030651. PMid:29534046.

WEBER, C.R., SOARES, C.M.L., LOPES, A.B.D., SILVA, T.S., NASCIMENTO, M.S. and XIMENES, E.C.P.A., 2011. Anadenanthera colubrina: a therapeutic potential study. Revista Brasileira de Farmácia, vol. 92, no. 4, pp. 235-244.

WORLD HEALTH ORGANIZATION - WHO, 2019 [viewed 20 February 2020]. Global report on traditional and complementary medicine 2019 [online]. Geneva: WHO. Available from: https://www. who.int/traditional-complementary-integrative- medicine/ WhoGlobalReportOnTraditional AndComplementaryMedicine 2019.pdf?ua $=1$

ZENKOV, N.K., CHECHUSHKOV, A.V., KOZHIN, P.M., KANDALINTSEVA, N.V., MARTINOVICH, G.G. and MENSHCHIKOVA, E.B., 2016. Plant phenols and autophagy. Biochemistry, vol. 81, no. 4, pp. 297-314. http://dx.doi.org/10.1134/S0006297916040015. PMid:27293088. 